\title{
Rearing of Thyrinteina Arnobia (Lepidoptera: Geometridae) on Guava and Eucalyptus in Laboratory
}

\author{
Harley Nonato de Oliveira ${ }^{1 *}$, José Cola Zanuncio ${ }^{2}$, Eder Pin Pedruzzi ${ }^{1}$ and Marcelo \\ Curitiba Espindula ${ }^{1}$ \\ ${ }^{1}$ Laboratório de Entomologia; CCA-UFES; C. P. 16; 29500-000; hnoliveira@insecta.ufv.br; Alegre - ES - Brasil. \\ ${ }^{2}$ Departamento de Biologia Animal; Universidade Federal de Viçosa; 36571-000; zanuncio@ufv.br; Viçosa - MG - \\ Brasil
}

\begin{abstract}
Thyrinteina arnobia, is one of the most important defoliating caterpillars of Eucalyptus in Brazil The objective of this work was to evaluate the development and the reproduction of feeding on leaves of guava (Psidium guajava) or Eucalyptus grandis in the $15^{\text {th }}$ generation, after rearing this species for 14 genrations on guava leaves. T. arnobia showed shorter larval period, better viability of caterpillars and pupae, heavier pupae, higher number of eggs per female, better egg viability and shorter longevity of females in guava leaves than in Eucalyptus leaves. The better development and reproduction with $\mathrm{P}$. guajava showed that this insect could be reared in laboratory with guava leaves.
\end{abstract}

Key words: Psidium guajava, defoliator, mass rearing, host, Eucalyptus grandis

\section{INTRODUCTION}

Female moths of Thyrinteina arnobia (Stoll) (Lepidoptera: Geometridae) shows white wings with scattered punctuations, filiform antennae and are larger than males which shows brown wings and pectinated antennae. Mating and egg laying of this insect occur during the night. Its egg masses are deposited around fine branches with up to 1000 eggs each batch and they are dark green when laid and progressively become darker and turn black near caterpillar hatching. Incubation period of eggs is around 10 days. Caterpillars of $T$. arnobia are known as "brown-color-caterpillar" and "brown-caterpillar" and are usually black. Caterpillars of $T$. arnobia show two conical saliencies in the head separated by a lower part, their lenght is about $50 \mathrm{~mm}$ and they have a chestnut tree-dark coloration when well developed, which can mimic them as small branches. The larval period of this insect lasts about 25 days and pupation occurs in Eucalyptus leaves and lasts about 10 days. T. arnobia begins feeding from the base to the top of trees and from the margin to the interior of Eucalyptus stands (Zanuncio et al., 1993).

T. arnobia also feeds on native plants such as Villaresia congonha, Ilex paraguaiensis, Campomanesia spp., Eugenia spp. and Psidium guajava (Chiarelli, 1943; Ferreira, 1980; Santos et al., 2000). Caterpillars of this species have been reported in most areas where Eucalyptus spp. is cultivated in Brazil (Zanuncio et al., 1997). Outbreak of this pest is believed to happen because this plant grows in extensive areas and during long periods with large food and shelter

\footnotetext{
*Author for correspondence
} 
availability (Santos et al., 1996). These conditions have allowed $T$. arnobia to cause serious damage to these plants (Anjos et al., 1987) and to become the most important eucalyptus defoliator in Brazil (Zanuncio et al., 1997).

This work evaluated the development and reproduction of $T$. arnobia in the $15^{\text {th }}$ generation feeding on leaves of $P$. guajava or Eucalyptus grandis, after rearing this species for 14 generations on guava leaves in the laboratory, aiming to determine the best diet to rear T. arnobia in laboratory.

\section{MATERIALS AND METHODS}

T. arnobia rearing started with pupae collected in eucalyptus plantations and brought to the laboratory where they were placed in PVC (Poly Vinyl Chlorid) tubes with $200 \mathrm{~mm}$ diameter and $25 \mathrm{~cm}$ height. Adults of this insect were transferred to $38 \times 41 \times 45 \mathrm{~cm}$ wood boxes just after emergence with a corrugated A4 paper in the internal walls as oviposition site. One side of these boxes was constituted by a glass door to facilitate handling of insects. Adults of T. arnobia received a $10 \%$ honey solution in anesthetic type tubes and its egg masses were collected and maintained daily in an acclimatized room at $25 \pm 3^{\circ} \mathrm{C}, 70 \pm 10 \%$ relative humidity and photophase of 12 hours. Eggs of T. arnobia were collected and maintained in Petri dishes $(9.0 \times 1.2 \mathrm{~cm})$ for hatching. Caterpillars were transferred to plastic cages $(15 \mathrm{x}$ $12 \mathrm{~cm}$ ) with guava leaves ( $P$. guajava) until pupation. This was repeated during 14 generations in an acclimatized room under the same conditions.

The experiment was developed with 120 caterpillars on first larval instar of T. arnobia at the $15^{\text {th }}$ generation after 14 generations with guava leaves ( $P$. guajava). These individuals were separated in two groups with sixty of them feeding on guava leaves and the other sixty on $E$. grandis leaves. Each caterpillar was individualized in a Petri dish $(15 \times 1.2 \mathrm{~cm})$ with a leaf of the respective host. A glass Duran type tube (3.0 x 0.5 $\mathrm{cm}$ ) with water was placed in the petiole to keep leaf turged. Cleaning and leaf change were made daily. Caterpillars of T. arnobia were kept in these plates until pupation and then transferred to 500 ml plastic pots until adult emergence. Fifteen pairs of $T$. arnobia were randomly chosen, formed per host and individualized in $500 \mathrm{ml}$ plastic pots with a $10 \%$ honey solution in anesthetic tubes type and paper as oviposition site.

Duration of larval, pre-pupal and pupal period weight of pupae, and viability of caterpillars and pupae were evaluated. Pre-oviposition and oviposition periods and numbers of egg masses, eggs per female and eggs per egg mass, besides viability of eggs and longevity of adults of $T$. arnobia were determined.

Analyses of variance at 5\% probability level were performed for all characteristics investigated.

\section{RESULTS}

The larval period of individuals of $T$. arnobia originated on eucalyptus leaves was longer than on guava leaves. Pre-pupal and pupal periods of this lepidopteran were similar between hosts but males showed longer pupal period than females with this host. Pupae that originated females were heavier than those of males with both hosts and pupae from caterpillars feeding on guava leaves were heavier than those fed on eucalyptus (Table 1). Caterpillars were transferred to plastic cages $(15 \mathrm{x}$ $12 \mathrm{~cm}$ ) with guava leaves ( $P$. guajava) until pupation. This was repeated during 14 generations in an acclimatized room under the same conditions.

Table 1 - Averages \pm standard error for larvae (PL), pre-pupae (PRP) and pupae (PP) periods and pupae weight (PSP) of Thyrinteina arnobia (Lepidoptera: Geometridae) fed with Psidium guajava or Eucalyptus grandis leaves in the $15^{\text {th }}$ generation after been reared during 14 generations on leaves of the first host in laboratory. $25 \pm 3^{\circ} \mathrm{C}, 70$ $\pm 10 \%$ relative humidity and fotofase of 12 hours.

\begin{tabular}{lrrrr}
\hline Parameters & \multicolumn{2}{c}{ Psidium guajava } & \multicolumn{2}{c}{ Eucalyptus grandis } \\
\hline & \multicolumn{1}{c}{ Females } & Males & \multicolumn{1}{c}{ Females } & \multicolumn{1}{c}{ Males } \\
PL (days) & $29.84 \pm 0.75 \mathrm{Ba}$ & $23.25 \pm 0.63 \mathrm{Bb}$ & $37.43 \pm 1.13 \mathrm{Aa}$ & $30.67 \pm 2.20 \mathrm{Ab}$ \\
PRP (days) & $1.95 \pm 0.09 \mathrm{Aa}$ & $1.92 \pm 0.08 \mathrm{Aa}$ & $1.93 \pm 0.07 \mathrm{Aa}$ & $2.00 \pm 0.08 \mathrm{Aa}$ \\
PP (days) & $10.47 \pm 0.21 \mathrm{Ab}$ & $11.50 \pm 0.15 \mathrm{Aa}$ & $10.21 \pm 0.15 \mathrm{Ab}$ & $11.50 \pm 0.22 \mathrm{Aa}$ \\
PSP (mg) & $680.56 \pm 16.04 \mathrm{Aa}$ & $280.46 \pm 8,30 \mathrm{Ab}$ & $550.03 \pm 18.16 \mathrm{Ba}$ & $230.28 \pm 15.14 \mathrm{Bb}$ \\
\hline
\end{tabular}

Mean of males or females followed by the same capital letter, in the line, are not different at 5\% of probability; mean of males and females in the same host followed by the same small letter are not different at $5 \%$ of probability. 
Table 2 - Biological aspects of Thyrinteina arnobia (Lepidoptera: Geometridae) adults from caterpillars fed with Psidium guajava or Eucalyptus grandis leaves in the $15^{\text {th }}$ generation after being reared during 14 generations with leaves of the first host in laboratory. $25 \pm 3^{\circ} \mathrm{C}, 70 \pm 10 \%$ relative humidity and fotofase of 12 hours.

\begin{tabular}{lrr}
\hline \multicolumn{1}{c}{ Parameters } & \multicolumn{1}{c}{ Psidium guajava } & Eucalyptus grandis \\
\hline Pre-oviposition (days) & $3.87 \pm 0.41 \mathrm{~A}$ & $4.47 \pm 0.45 \mathrm{~A}$ \\
Oviposition (days) & $3.73 \pm 0.56 \mathrm{~A}$ & $3.65 \pm 0.33 \mathrm{~A}$ \\
Number of egg masses & $4.33 \pm 0.61 \mathrm{~A}$ & $3.65 \pm 0.27 \mathrm{~A}$ \\
Total number of eggs/female & $861.87 \pm 103.43 \mathrm{~A}$ & $460.65 \pm 63.84 \mathrm{~B}$ \\
Number of eggs/egg mass & $305.92 \pm 52.53 \mathrm{~A}$ & $139.13 \pm 25.17 \mathrm{~B}$ \\
Egg viability (\%) & $88.75 \pm 3.20 \mathrm{~A}$ & $63.50 \pm 7.35 \mathrm{~B}$ \\
Larvae viability (\%) & $80.00 \pm 6,41 \mathrm{~A}$ & $57.50 \pm 7.42 \mathrm{~B}$ \\
Pupae viability (\%) & $96.88 \pm 3.13 \mathrm{~A}$ & $82.35 \pm 9.53 \mathrm{~B}$ \\
\hline
\end{tabular}

Mean followed by the same capital letter in the line are not different at 5\% of probability.

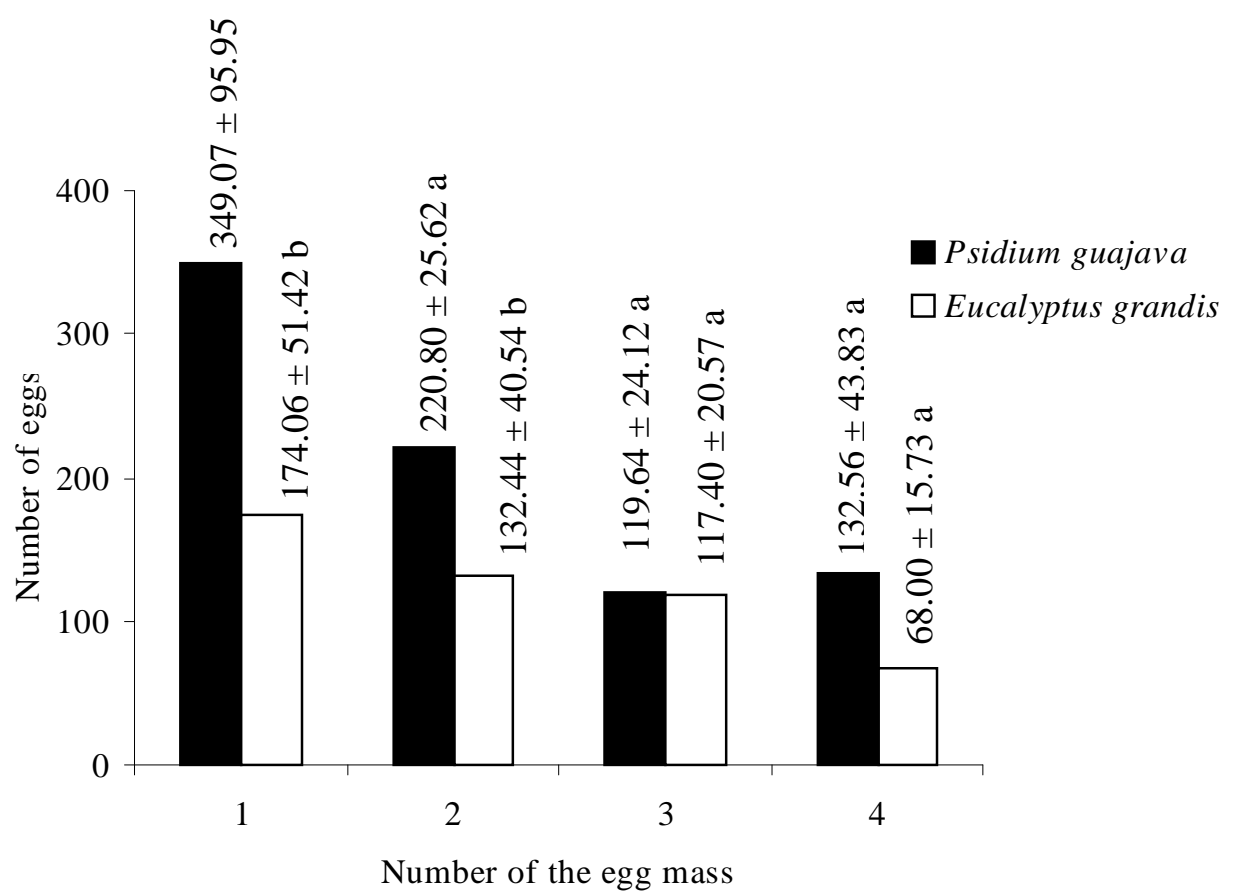

Figure 1 - Number of eggs/egg mass per female of Thyrinteina arnobia (Lepidoptera: Geometridae) in the $15^{\text {th }}$ generation from caterpillars reared with Psidium guajava or Eucalyptus grandis after 14 generations fed on leaves of the first host. Means followed by the same letter per egg mass are not different at $5 \%$ probability.

Pre-oviposition and oviposition periods and number of egg masses were similar with guava and eucalyptus. However, the number of eggs/female, eggs/egg mass and viability of eggs, caterpillars and pupae of T. arnobia showed higher values with guava leaves (Table 2).

Females of $T$. arnobia fed with guava leaves showed in the first and second egg masses higher number of eggs. The number of caterpillars per female was higher in the first, second and fourth egg masses with guava leave (Fig. 1 and 2).

T. arnobia females showed longer longevity with eucalyptus but that of males was similar between treatments. Females of this lepidopteran showed longer longevity than males in both treatments (Fig. 3). 


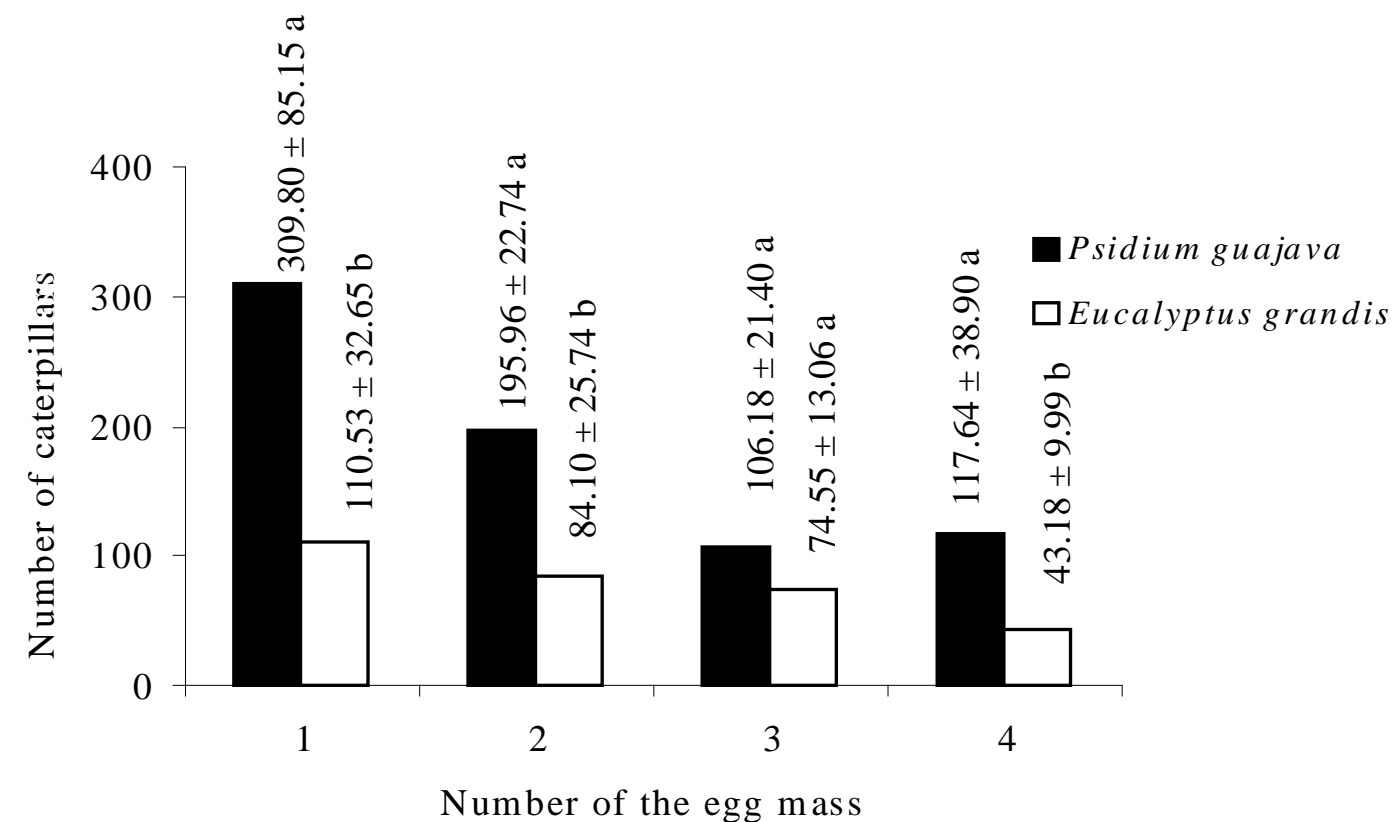

Figure 2 - Number of caterpillars hatched per egg mass per female of Thyrinteina arnobia (Lepidoptera: Geometridae) from caterpillars reared with Psidium guajava or Eucalyptus grandis in the $15^{\text {th }}$ generation after 14 generations fed on leaves of the first host. Means followed by the same letter per egg mass are not different at $5 \%$ probability.

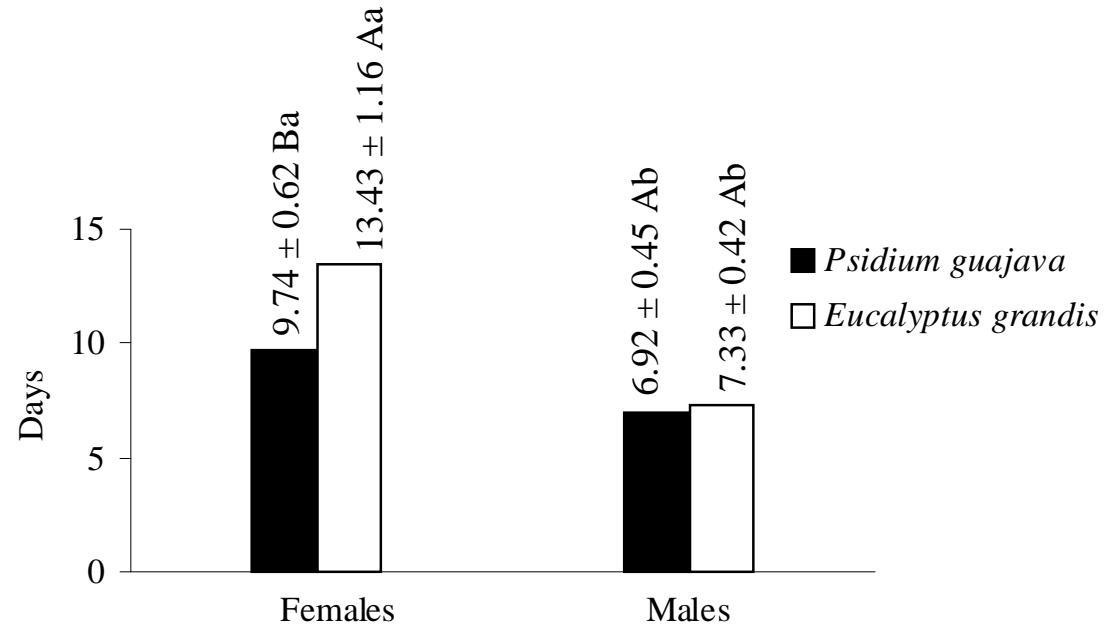

Figure 3 - Longevity of adults of Thyrinteina arnobia (Lepidoptera: Geometridae) whose caterpillars were fed on Psidium guajava or Eucalyptus grandis leaves in the $15^{\text {th }}$ generation after been reared during 14 generations with leaves of the first host. Means followed by the same capital letter for females or males between treatments and lower case letters between males and females in the same host are not different at $5 \%$ probability. 


\section{DISCUSSION}

The shortest duration of the larval stage of individuals of $T$. arnobia that originated males or females on guava leaves agreed with Santos et al. (2000) and Holtz et al. (2003a). Larval period of caterpillars fed on guava leaves which originated females was also shorter than on $E$. grandis which has been considered one of the best food sources for T. arnobia (Lemos et al., 1999). The longest duration of the larval stage of $T$. arnobia fed on eucalyptus leaves could be due to the negative impact of secondary compounds of these plants (Penfold and Willis, 1961; Hill, 1966; Fox and Macauley, 1977). Females of T. arnobia showed longer larval period than males in both hosts. This may have occurred because females are larger and need a longer feeding period to accumulate nutrients and to produce eggs (Panizzi and Parra, 1991; Santos et al. 2000).

Heavier weight and higher viability of $T$. arnobia pupae with guava leaves indicated that this host had higher nutritional quality and also that this lepidopteran was better adaptated to this plant.

T. arnobia showed higher values for numbers of eggs/egg mass, total eggs/female and viability of eggs with guava than with eucalyptus leaves. This disagreed with Holtz et al. (2003b) who found higher values for these parameters when $T$. arnobia was reared on eucalyptus after four generations on this plant or with eucalyptus leaves in laboratory. These authors considered that this adaptation period was enough for chemical compounds present in this plant to affect populations of this herbivore in the original host (guava) but not in the introduced one (eucalyptus). Numbers of eggs and caterpillars per female per egg mass of $T$. arnobia were also higher with guava than with eucalyptus leaves. Again, this indicated a worse nutritional quality and digestibility of leaves of $E$. grandis due to presence of secondary compounds such as essential oils and tannins, which could reduce availability of proteins for herbivores (Jãremo, 1999; Penfold and Willis, 1961). This was demonstrated by the fact that tannins stored in oak leaves and other plants could be combined with proteins of leaves and digestive enzymes in the intestine of herbivores, which could hinder the digestion of proteins (Panizzi and Parra, 1991). This could reduce the absorption of nutrients and the reproduction of insects (Berennbaum and Zangerl, 1996).

Longevity of $T$. arnobia males was similar between treatments but this was shorter for females originated from caterpillars feeding on guava leaves. Shorter longevity with leaves of this host could be due to the higher number of eggs laid by $T$. arnobia when feeding with guava leaves. This could led to an allocation of energy between different physiologic processes with increment of one of them (reproduction) and decrease of another (longevity) (Sibly and Calow, 1986). For this reason the increase on number of eggs deposited could reduce the energy available with a consequent reduction on longevity.

The results showed that leaves of $P$. guajava represented a better host to maintain and to multiply $T$. arnobia in laboratory conditions.

\section{ACKNOWLEDGEMENTS}

We thank to Conselho Nacional de Desenvolvimento Científico e Tecnológico (CNPq) and Fundação de Amparo à Pesquisa do Estado de Minas Gerais (FAPEMIG), for support.

\section{RESUMO}

Thyrinteina arnobia, é umas das mais importantes lagartas desfolhadoras de eucalipto no Brasil. O objetivo desse trabalho foi avaliar o desenvolvimento e a reprodução desse lepidóptero em folhas de goiabeira (Psidium guajava) e Eucalyptus grandis, na $15^{\circ}$ geração, após criar essa espécie por 14 gerações em folhas de goiabeira. T. arnobia apresentou menor período larval, maior viabilidade de lagartas e de pupas, maior peso pupal, maior número de ovos totais por fêmea e viabilidade de ovos e menor longevidade de fêmeas com folhas de goiabeira. Além disso, teve melhor desempenho e reprodução com $P$. guajava, do que com folhas de E. grandis, mostrando que esse inseto pode ser criado com folhas de goiabeira em laboratório. 


\section{REFERENCES}

Anjos, N.; Santos, G. P. and Zanuncio, J. C. (1987), A lagarta-parda, Thyrinteina arnobia Stoll, 1782 (Lepidoptera: Geometridae) desfolhadora de eucaliptos. Boletim Técnico, 25, EPAMIG. 56.

Berennbaum, M. R. and Zangerl, A. R. (1996), Constraints on chemical coevolution: wild parsnips and the parsnip webworn. Evolution, 40, 1215-1228.

Chiarelli, A. (1943), Um geometrídeo prejudicial a la yerba mate, Thyrinteina arnobia. Revista Argentina de Agronomia, 10, 250-255.

Fox, L. R. and Macauley, B. J. (1977), Insect grazing of Eucalyptus in response to variation in leaf tannins and nitrogen. Oecologia, 29, 145-162.

Ferreira, M. B. (1980), Frutos comestíveis nativos do cerrado em Minas Gerais. Informe Agropecuário, 6, 9-18.

Hill, W. E. (1966), Polyphenols in the leaves of Eucalyptus L'Herit a Chemotaxonomics survey: Introduction and study of the series globulares. Phytochemistry, 5, 1075-1090.

Holtz, A. M.; Oliveira, H. G.; Pallini, A.; Marinho, J S.; Zanuncio, J. C. and Oliveira, C. L. (2003a), Adaptação de Thyrinteina arnobia em novo hospedeiro e defesa induzida por herbívoros em eucalipto. Pesquisa Agropecuária Brasileira, 38, 453-458.

Holtz, A. M.; Oliveira, H. G.; Pallini, A.; Venzon, M.; Zanuncio, J. C.; Oliveira, C. L.; Marinho, J. S. and Rosado, M. C. (2003b), Desempenho de Thyrinteina arnobia Stoll (Lepidoptera: Geometridae) em eucalipto e goiaba: o hospedeiro nativo não é um bom hospedeiro?. Neotropical Entomology, 32, 427-431.

Jãremo, J. (1999), Plant adaptations to herbivory: mutualistc versus antagonistic coevolution. Oikos, 84, 313-320.

Lemos, R. N. S.; Crocomo, W. B.; Forti, L. C. and Wilcken, C. F. (1999), Seletividade alimentar e influência da idade da folha de Eucalyptus spp. para Thyrinteina arnobia (Lepidoptera: Geometridae). Pesquisa Agropecuária Brasileira, 34, 7-10.

Panizzi, A. R. and Parra, J. R. P. (1991), Ecologia nutricional de insetos e suas aplicações no manejo de pragas. São Paulo: Manole. pp. 391.

Penfold, A. R. and Willis, J. L. (1961), The Eucalyptus. New York: Interscience. pp. 551.
Santos, G. P.; Zanuncio, J. C. and Zanuncio, T. V. (1996), Pragas do eucalipto. Informe Agropecuário, 18, 66-71.

Santos, G. P.; Zanuncio, T. V. and Zanuncio, J. C. (2000), Desenvolvimento de Thyrinteina arnobia Stoll (Lepidoptera: Geometridae) em folhas de Eucalyptus urophylla e Psidium grajava. Anais da Sociedade Entomológica do Brasil, 29, 13-22.

Sibly, R. M. and Calow, P. (1986), Physiological ecology of animals an evolutionary. Blackwell Scientific Publications. pp. 179.

Zanuncio, J. C.; Alves, J. B. and Zanuncio, T. V. (1993), Descrição das lagartas desfolhadoras. In: Manual de pragas em florestas lepidoptera desfolhadoras de eucalipto: biologia, ecologia $e$ controle. IPEF/SIF. pp.140.

Zanuncio, T. V.; Zanuncio, J. C.; Gonçalves, R. C. and Oliveira, A. C. (1997), Morfologia e bionomia de Thyrinteina leucoceraea Rindge (Lep., Geometridae) alimentada com Eucalyptus urophylla. Revista Brasileira de Entomologia, 41, 5-8.

Received: January 28, 2004; Revised: September 03, 2004; Accepted: March 01, 2005 